\title{
SUBSTANTIATION OF APPLICATION OF EM-PRODUCTS IN CLOSED RESOURCE-SAVING AGROECO COMPLEXES
}

\author{
ОБГРУНТУВАННЯ ВИКОРИСТАННЯ \\ ЕМ-ПРЕПАРАТІВ У ЗАМКНЕНИХ \\ РЕСУРСОЗБЕРІГАЮЧИХ АГРОЕКОКОМПЛЕКСАХ
}

\section{Mykola Kovalov ${ }^{1}$}

DOI: https://doi.org/10.30525/978-9934-26-001-8-3-10

Abstract. The article presents technological methods of creating closed resource-saving agroeco complexes in organic agricultural production based on the use of EM products at all stages of closed interconnected biological cycles, which will operate through trophic and energy chains and provide consumers with environmentally friendly vegetable products.

Considering quick aggravation of environmental problems, including agricultural sector (soil fertility, wind and water erosion, reduced quantitative and qualitative yields of vegetable and livestock products), there is an urgent need to develop and implement the latest environmentally balanced and safe systems management. As foreign experience shows, such technologies lead to the improvement of the agri-environmental situation in general.

Therefore, in our research, we offer a number of technological techniques that will operate on the basis of three components, namely the utilization of crop residues in the cultivation of basidiomycetes in an intensive way, production of EM composts and their further use as fertilizers in organic vegetables.

The main objective of our research is to develop the technology that would create a modern balanced agroeco complex. As a result, a consumer will be provided with environmentally friendly vegetable products, as all technological processes that will occur at any stage will be biological or organic. To achieve this goal it was necessary to solve the following tasks:

1) To develop the technology of using crop residues with their fermentation by EM products as a substrate in the cultivation of basidiomycetes;

\footnotetext{
${ }^{1} \mathrm{PhD}$ of Agriculture, Senior Lecturer at the Department of Geoponics, Central Ukrainian National Technical University, Ukraine.
} 
2) To develop the technology of utilization of the used mushroom beds with the help of EM products and to make composts;

3) To develop the technology of using composts together with EM products for growing vegetable products in open and protected soil.

These three technological components ensure full viability of the agroeco-complex in compliance with all ecological principles enshrined in the concept of organic farming, namely the proposed techniques can restore lost ecological functions of soils and maintain health of ecosystems and consumers.

The proposed technological methods of the organization of agroeco complex will ensure ecological safety of agricultural products, creating closed cycles of production, resource conservation, monitoring of all stages of production and product control, energy independence of the agrocomplex at all stages of agricultural production.

\section{Introduction}

The Ukrainian agriculture has been actively developing at the beginning of the new millennium,. In today's rather harsh conditions, obtaining environmentally friendly crop products forces most farmers to gradually master rather complex organic technologies [1, p. 197].

One of the most important concepts in the application of organic technology is the use of biologicals. In our opinion, the most promising is the use of Effective Microorganisms for stable symbiosis with plants, which helps to provide them with nutrition and suppression of pathogenic microflora.

Therefore, application of EM products in modern closed systems of agroeco complexes is one of most promising areas of agricultural production in the XXI century. The founder of EM technology is a Japanese professor, microbiologist Teruo Higa [2, p. 128]. In 1988, he managed to create a super-compound complex of beneficial bacteria, which he called effective microorganisms (EM). He selected 86 leading regenerative strains that performed a full range of functions for plant nutrition, protection from disease and improvement of soil environment.

The success of the application of these products was stunning. With the creation of EM-product, a new agricultural EM-technology was created which marked the beginning of a new era of organic farming. 
Organizations that actively promote the introduction of organic farming include: Organic Services from Germany, Food and Agricultural Organization (FAO), the European Commission (EU), the International Federation of Organic Agricultural Movement (IFOAM), "Federation of Organic Movement of Ukraine" and LLC "EM Ukraine" in Ukraine.

In our country, the area of land under organic production is only $0.4-0.6 \%$. At the same time, Ukraine has a huge potential for the production of organic agricultural products to export and for domestic consumption. Along with the positive trends in the introduction of organic farming, there is a significant problem among Ukrainian eco-farmers, which is the marketing of their products. Low environmental education of Ukrainian consumers leads to low demand for this type of product, because its price is significantly higher than the products of traditional agriculture.

With growing consumer demand for organic products, organic farming offers alternative strategies for rural development, thus increasing economic, social and environmental prosperity.

The main objective of our research is to develop the technology that would create a modern balanced agroeco complex. As a result, a consumer will be provided with environmentally friendly vegetable products, as all technological processes that will occur at any stage will be biological or organic. To achieve this goal it was necessary to solve the following tasks:

1) To develop the technology of using crop residues with their fermentation by EM products as a substrate in the cultivation of basidiomycetes;

2) To develop the technology of utilization of the used mushroom beds with the help of EM products and to make composts;

3) To develop the technology of using composts together with EM products for growing vegetable products in open and protected soil.

\section{Formation of productivity of Oyster mushroom under the influence of EM products}

At the beginning of the XXI century in terms of industrial cultivation of Pleurotus ostreatus is in second place after champignons. Deservedly, this type of mushroom is considered a dietary product that has high nutritional and medicinal properties, and also contains a huge amount of vitamins and nutrients (potassium, magnesium, iron, cobalt, etc.), minerals and biologically active substances. At the same time, oyster mushroom is 
hypoallergenic, which allows using it in any form with almost no restrictions. High nutritional value of Pleurotus ostreatus is due to the relatively high content of protein $-50.3 \%$, carbohydrates $-3.0-5.0 \%$, fat $-0.2-2.5 \%$, extractives substances - up to $45.0 \%$.

\subsection{Influence of EM products on the formation of productivity of most common strains of Oyster mushroom}

One of the most important issues in the industrial technology of cultivation of Pleurotus ostreatus is the preparation of straw substrate. The "hot" method includes the following techniques: sterilization, pasteurization, hydrothermal treatment, xerothermal treatment and fermentation. This method increases the cost price of the product due to technological and energy costs.

The experiments were conducted on the basis of Geoponics Department at Central Ukrainian National Technical University during 2018-2019 according to the methodology of A.I. Ivanov [3, p. 485]. The objective of our research was to determine the productivity of different strains of oyster mushroom depending on the type of straw substrate. The following tasks were solved:

1. To evaluate different types of straw substrates and determine their nutritional value;

2. To assess biological productivity of fungal beds depending on the method of their treatment and select the most high-productive simplifying of technological process of straw substrate preparation for further inoculation in the conditions of protected soil.

The presence of nutrients such as total content of nitrogen and phosphorus are the factors that limit colonization of the substrate and also directly affect the level of fruiting. Thus, the total content of nitrogen and phosphorus did not change on the same type of substrates with the cold method of treatment using EM products. At the same time, in the control variants, the value of these indicators was almost twice smaller. This is primarily due to the leaching of nutrients during heat treatment of the substrate (Table 2.1).

At the same time, the nutrients of the substrates can be assimilated by the mycelium at certain values of the acidity of the nutrient medium. Most species of fungi prefer a weakly acidic reaction of the nutrient medium, as well as competitive microflora, a bright representative of which is Trichodérma víride. 


\section{Dependence of the main indicators of substrates on the methods of their treatment}

\begin{tabular}{|l|c|c|c|}
\hline \multirow{2}{*}{\multicolumn{1}{|c|}{ Indicator }} & \multicolumn{3}{|c|}{ Type of treatment * } \\
\cline { 2 - 4 } & $\begin{array}{c}\text { Pasteurization + } \\
\text { lime carbonate }\end{array}$ & $\begin{array}{c}\text { Cold steeping } \\
\text { + EM Bio }\end{array}$ & $\begin{array}{c}\text { Cold steeping } \\
\text { + EM Agro }\end{array}$ \\
\hline Total content of nitrogen, \% & $0,2 / 0,17$ & $0,56 / 0,48$ & $0,55 / 0,48$ \\
\hline Total content of phosphorus, \% & $0,18 / 0,15$ & $0,53 / 0,46$ & $0,54 / 0,45$ \\
\hline Substrate moisture, \% & $75 / 73$ & $58 / 65$ & $65 / 58$ \\
\hline $\mathrm{pH}$ & $7,9 / 7,9$ & $6,5 / 6,5$ & $6,7 / 6,6$ \\
\hline $\mathrm{SSD}_{0,95}$ & 8,09 & 5,72 & 4,68 \\
\hline
\end{tabular}

* Note: the value for barley straw is in the numerator, and the value for wheat straw is in the denominator.

Since we used the cold method of treatment of the substrate on the fermentation variants of EM products [4], so in the control variant we added slaked lime at $1 \mathrm{~kg} / \mathrm{m}^{3}$ to artificially change the acidity level to the alkaline direction.

The rate of growth and development of oyster mushrooms is a very important indicator which characterizes the relationship between cultivation conditions and morphological and biological characteristics of strains of Oyster mushrooms. When creating optimal growing conditions, the process of growth and development of the fungal becomes more intense. In our studies, the onset of phenological phases of growth and development of the fungal depended on both the fungal strain and the supply of a particular type of substrate with nutrients. And this, in turn, later affected the total productivity and marketability of fruiting bodies of new strains of Oyster mushroom. The productivity of oyster mushrooms consisted of two waves of fruiting, which in total was its total productivity. Fungal fruits were characterized by the same shape, had a specific strain of colour and met the established technological requirements for cultivation.

When assessing the effectiveness of the influence of the supply of substrates with nutrients on the productivity of oyster mushrooms, the advantage of the substrate, which was based on barley straw (Table 2.2), was determined. 
Table 2.2

\section{Influence of substrate composition on productivity} of oyster mushroom, $\mathrm{kg} / \mathrm{m} 2$

\begin{tabular}{|c|c|c|c|c|c|c|}
\hline Strains & Substrate & $\begin{array}{c}\text { Addition } \\
\text { to control, } \\
\mathrm{kg} / \mathrm{m}^{2}\end{array}$ & $\begin{array}{l}\text { Presence of } \\
\text { competing } \\
\text { microflora }\end{array}$ & $\begin{array}{l}\text { I harvest, } \\
\mathrm{kg} / \mathrm{m}^{2}\end{array}$ & $\begin{array}{l}\text { II harvest, } \\
\mathrm{kg} / \mathrm{m}^{2}\end{array}$ & $\begin{array}{c}\text { Total } \\
\text { produc- } \\
\text { tivity, } \\
\mathbf{k g} / \mathbf{m}^{2}\end{array}$ \\
\hline \multirow{2}{*}{ M 9} & wheat & 2,8 & absent & 15,3 & 2,5 & 17,8 \\
\hline & barley & 3,0 & absent & 15,4 & 2,6 & 18,0 \\
\hline \multirow{2}{*}{ K 12} & wheat & 3,0 & absent & 15,5 & 2,8 & 18,3 \\
\hline & barley & 3,1 & absent & 15,6 & 2,9 & 18,5 \\
\hline \multirow{2}{*}{ K 17} & wheat & 3,0 & absent & 15,5 & 3,0 & 18,5 \\
\hline & barley & 3,1 & absent & 15,6 & 3,0 & 18,6 \\
\hline \multirow{2}{*}{$\mathrm{CB}$} & wheat & 2,9 & absent & 15,7 & 2,8 & 18,5 \\
\hline & barley & 3,1 & absent & 15,7 & 3,0 & 18,7 \\
\hline
\end{tabular}

The advantage in productivity is due primarily to the increased total content of nitrogen and phosphorus in the substrate, which stimulated intensive growth of mycelium and the formation of a large number of fungal fruits. The weight of fruits of the studied strains of the mushrooms M-9, K-12, K-17 and CB on barley straw was $18.0 ; 18.5 ; 18.6$ and $18.7 \mathrm{~kg} / \mathrm{m}^{2}$, respectively. That exceeded total productivity of fungal fruits of the control variant by 1.2 times. In addition to the positive effect of the substrate, there was a tendency to decrease the productivity of fungal fruits of oyster mushroom on the substrate, which was based on wheat straw for all studied strains.

Analyzing the beginning of fruiting, we concluded that on the control beds it began 6-8 days later than on the fermented beds and their biological productivity was much lower (1600-1900 g vs. 2800-3100 g). Indicators of the generative stage are given in Table 2.3.

Analysis of biological productivity and fruiting time clearly shows in favour of the fermented substrate. The weight of fruiting druses was also greater than $900 \pm 200 \mathrm{~g}$ against $450 \pm 50 \mathrm{~g}$. There was an increase in fruiting in the bed which was developed by us. We used fermentation method. The difference between the fermentation method and usual technology was (3100 g against $1900 \mathrm{~g}$ ).

Contrasting differences in productivity, in our opinion, can be explained by the fact that the fermentation of straw substrate with EM products is 


\section{Biological productivity of fungal beds depending on the method of their treatment}

\begin{tabular}{|l|c|c|c|c|}
\hline & \multirow{2}{*}{$\begin{array}{c}\text { Number of } \\
\text { days after } \\
\text { Types of bed } \\
\text { inoculation } \\
\text { before the } \\
\text { appearance } \\
\text { druses }\end{array}$} & $\begin{array}{c}\text { Average } \\
\text { weight of a } \\
\text { druse, } \mathbf{g}\end{array}$ & $\begin{array}{c}\text { Diameter of } \\
\text { a mushroom } \\
\text { cap, cm }\end{array}$ & $\begin{array}{c}\text { Total } \\
\text { productivity, g }\end{array}$ \\
\hline $\begin{array}{l}\text { Cold steeping + } \\
\text { lime carbonate }\end{array}$ & 25 & $450 \pm 50$ & $7-12$ & $1900 \pm 300$ \\
\hline EM Bioactive & 17 & $900 \pm 200$ & $5-10$ & $3100 \pm 300$ \\
\hline EM Agro & 19 & $900 \pm 200$ & $5-10$ & $3100 \pm 300$ \\
\hline
\end{tabular}

not only the splitting of lignin [5, p. 49], but also complete disinfection. At the same time, the unfermented straw substrate during pasteurization only increased the $\mathrm{pH}$ of the substrate in the alkaline direction. There was no process of destruction of hemicellulose and lignin.

\subsection{Productivity of exotic species of oyster mushrooms under the influence of EM products}

In Ukraine the share of industrial cultivation of exotic species of mushrooms is $2.5 \%$ of the total. Pink oyster mushroom or Flamingo (Pleurotus djamor) and Ilmak or Golden oyster mushroom (Pleurotus citrinopileatus) are no exception. Both mushrooms are quite rare edible mushrooms with a pleasant taste and original aroma. With intensive cultivation of exotic species of oyster mushrooms, it is possible to get a high quality environmentally friendly product. Oyster mushrooms are basidiomycetes in which fungal fruits consist of a cap that smoothly evolves into a stipe [6, p. 49].

The scheme of the experiment:

1) Soaking the straw substrate in water with the addition of lime carbonate in the amount of $1 \mathrm{~g} / \mathrm{l}$ at the ambient temperature of $25^{\circ} \mathrm{C}$ for 36 hours (control);

2) Soaking the straw substrate in $1.5 \%$ working solution of EM Bioactive at the ambient temperature of $25^{\circ} \mathrm{C}$ for 36 hours;

3) Soaking the straw substrate in $1.5 \%$ working solution of EM Agro at the ambient temperature of $25^{\circ} \mathrm{C}$ for 36 hours; 
4) Soaking the straw substrate in $1.5 \%$ working solution of EM Bokashi at the ambient temperature of $25^{\circ} \mathrm{C}$ for 36 hours.

EM Agro is the substance of live cultures of Effective Microorganisms, which include: lactic acid, photosynthesizing, nitrogen fixing, yeast, actinomycetes, sugar cane molasses, and water;

EM Bioactive is a special complex of live cultures of Effective Microorganisms which includes: photosynthetic, lactic acid, yeast, actinomycetes, nitrogen-fixing, sugar cane molasses, and water. The difference between EM Agro and EM Bioactive is the method of activation.

EM Bokashi is a special complex containing Effective Microorganisms: lactic acid, photosynthetic, yeast, actinomycetes.

The accounting unit is one bag measuring $35 \times 90 \mathrm{~cm}$, filled with substrate (7 kg). Repeatability is fourfold.

The presence of nutrients such as total content of nitrogen and phosphorus are the factors that limit the colonization of the substrate and also directly affect the level of fruiting [7, p.79]. Thus, the total content of nitrogen and phosphorus on the same type of substrates with the cold method of treatment using EM products did not change. At the same time, in the control variants, the value of these indicators was almost twice smaller. This is primarily due to the increase in substrate moisture due to the application of lime carbonate (Table 2.4).

Table 2.4

\section{Dependence of the main indicators of substrates on the methods of their treatment}

\begin{tabular}{|l|c|c|c|}
\hline \multirow{2}{*}{ Type of treatment } & \multicolumn{3}{|c|}{ Indicator* } \\
\cline { 2 - 4 } & $\begin{array}{c}\text { Total content of } \\
\text { nitrogen, \% }\end{array}$ & $\begin{array}{c}\text { Total content of } \\
\text { phosphorus, \% }\end{array}$ & pH \\
\hline 1 (control) & $0,2 / 0,17$ & $0,18 / 0,15$ & $7,9 / 7,9$ \\
\hline 2 & $0,56 / 0,48$ & $0,53 / 0,46$ & $5,6 / 5,8$ \\
\hline 3 & $0,55 / 0,48$ & $0,54 / 0,45$ & $5,5 / 5,6$ \\
\hline 4 & $0,65 / 0,55$ & $0,57 / 0,49$ & $5,7 / 5,8$ \\
\hline $\mathrm{SSD}_{0,95}:$ & \multicolumn{3}{|c}{} \\
general & \multicolumn{3}{|c|}{0,81} \\
by factor A \\
by factor B
\end{tabular}

* Note: the value for barley straw is the numerator, and the value for wheat straw is the denominator. 
During the period of oyster mushroom cultivation, phenological observations were made: the dates of inoculation and germination of the mycelium, the appearance of fungal fruits; the beginning and end of fruiting of the I and II harvests were noted; biometric measurements: length and diameter of stipes and caps, harvest accounting by weighing foulings of fungal fruits. The productivity of exotic species of Oyster mushrooms was determined on the basis of the ratio of the mass of harvested fungal fruits to the mass of the fermented substrate. Productivity data were processed by the method of analysis of variance by B.A. Dospekhov [8, p. 228]. As a result of the research, the duration of the incubation period and the beginning of fruiting of the studied fungal strains were established (Table 2.5).

Table 2.5

Dates of beginning of phenological phases of development of Oyster mushroom

\begin{tabular}{|c|c|c|c|c|c|c|}
\hline 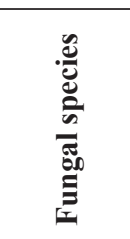 &  & 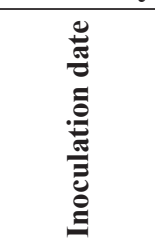 & 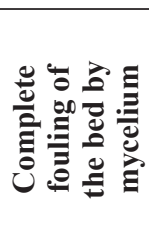 &  & 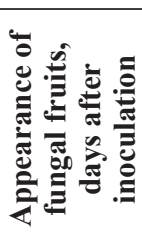 & 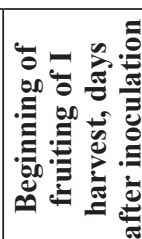 \\
\hline \multirow{2}{*}{$\begin{array}{c}\text { Flamingo } \\
\text { (control) }\end{array}$} & wheat & 08.07 .2019 & 35 & absent & 38 & 44 \\
\hline & barley & 08.07 .2019 & 35 & absent & 38 & 44 \\
\hline \multirow{2}{*}{$\begin{array}{c}\text { Ilmak } \\
\text { (control) }\end{array}$} & wheat & 08.07 .2019 & 34 & absent & 39 & 45 \\
\hline & barley & 08.07 .2019 & 34 & absent & 39 & 45 \\
\hline \multirow{2}{*}{ Flamingo } & wheat & 08.07 .2019 & 22 & absent & 25 & 31 \\
\hline & barley & 08.07 .2019 & 21 & absent & 24 & 30 \\
\hline \multirow{2}{*}{ Ilmak } & wheat & 08.07 .2019 & 21 & absent & 24 & 30 \\
\hline & barley & 08.07 .2019 & 20 & absent & 23 & 30 \\
\hline
\end{tabular}

Complete mycelial fouling of beds with the substrate without treatment with EM products (control) occurred 35 days after inoculation, that is 15 days later. Moreover, local infection with Trichodérma víride was observed in all control units [9, p. 37]. It should be noted that the beginning of fruiting on the control beds began 13-14 days later than on the fermented ones, and the degree of their stromal lesions with Trichodérma víride ranged from 5 to 
$25 \%$. This explains the large discrepancy between the periods of fouling and fruiting in the control variants.

When evaluating the effectiveness of the influence of the supply of substrates with nutrients on the productivity of oyster mushrooms, the advantage of the substrate, which was based on barley straw [10, p. 87], was determined. Indicators of the generative stage are given in Table 2.6.

Table 2.6

Biological productivity of fungal beds depending on the method of their treatment

\begin{tabular}{|c|c|c|c|c|c|}
\hline \multirow[b]{2}{*}{$\begin{array}{c}\text { Type } \\
\text { of bed } \\
\text { treatment }\end{array}$} & \multirow[b]{2}{*}{$\begin{array}{l}\text { Fungal } \\
\text { species }\end{array}$} & \multirow[b]{2}{*}{ Substrate } & \multicolumn{3}{|c|}{ Biological productivity } \\
\hline & & & $\begin{array}{l}\text { Average } \\
\text { weight of } \\
\text { fouling, } g\end{array}$ & $\begin{array}{c}\text { Cap diameter, } \\
\text { cm }\end{array}$ & $\begin{array}{c}\text { Productivity } \\
\text { of the I } \\
\text { harvest, } g / \\
\text { sack }\end{array}$ \\
\hline \multirow{4}{*}{1} & \multirow{2}{*}{ Flamingo } & wheat & $425 \pm 50$ & $3-5$ & $850 \pm 50$ \\
\hline & & barley & $450 \pm 50$ & & $900 \pm 50$ \\
\hline & \multirow{2}{*}{ Ilmak } & wheat & $425 \pm 50$ & $3-6$ & $850 \pm 50$ \\
\hline & & barley & $450 \pm 50$ & & $900 \pm 50$ \\
\hline \multirow{4}{*}{2} & \multirow{2}{*}{ Flamingo } & wheat & $800 \pm 100$ & $5-8$ & $1600 \pm 100$ \\
\hline & & barley & $850 \pm 100$ & & $1700 \pm 100$ \\
\hline & \multirow{2}{*}{ Ilmak } & wheat & $800 \pm 100$ & $4-8$ & $1600 \pm 100$ \\
\hline & & barley & $900 \pm 100$ & & $1800 \pm 100$ \\
\hline \multirow{4}{*}{3} & \multirow{2}{*}{ Flamingo } & wheat & $822 \pm 100$ & $5-8$ & $1644 \pm 100$ \\
\hline & & barley & $855 \pm 100$ & & $1710 \pm 100$ \\
\hline & \multirow{2}{*}{ Ilmak } & wheat & $800 \pm 100$ & $4-8$ & $1600 \pm 100$ \\
\hline & & barley & $925 \pm 100$ & & $1850 \pm 100$ \\
\hline \multirow{4}{*}{4} & Flamingo & wheat & $750 \pm 100$ & $5-8$ & $1500 \pm 100$ \\
\hline & Flamingo & barley & $760 \pm 100$ & $5-8$ & $1510 \pm 100$ \\
\hline & \multirow{2}{*}{ Ilmak } & wheat & $790 \pm 100$ & $4-8$ & $1580 \pm 100$ \\
\hline & & barley & $830 \pm 100$ & & $1660 \pm 100$ \\
\hline
\end{tabular}

The advantage in productivity is due primarily to the increased content of total content of nitrogen and phosphorus in the substrate, which stimulated intensive growth of mycelium and the formation of a large number of fungal fruits. The mass of fungal fruits of the studied species of the Pink Mushroom on barley straw was 1700; 1710; and $1510 \mathrm{~g} / \mathrm{bag}$, respectively, 
which exceeded the total yield of fungal fruits of the control variant by 1.7-2.0 times. For the Golden Mushroom, the yield on barley straw was slightly higher - 1800; 1860 and $1660 \mathrm{~g} / \mathrm{bag}$, that is in comparison with the control variants it was 1.8-2.0 times higher. The yield of mushroom beds using EM Bokashi was slightly lower than with EM Agro and EM Bioactive. In our opinion, this is due to the specifics of the product itself, because the fungal bed of the fourth variant sometimes showed the germination of mycelial grains, which ultimately affected the reduction in productivity of fungal fruits.

The analysis of biological productivity and fruiting time clearly shows the benefits of the fermented substrate. The weight of fungal fruits was also greater than $900 \pm 200 \mathrm{~g}$ against $450 \pm 50$. Increase in fruiting of one bed developed by us by the fermentation method using usual technology of $3100 \mathrm{~g}$ against $1900 \mathrm{~g}$.

Contrasting differences in productivity, in our opinion, can be explained by the fact that the fermentation of straw substrate by EM-products is not only the breakdown of lignin [11, p. 15], but also complete disinfection. At the same time, the unfermented straw substrate in the control variants only increased the level of acidity of alkaline. This, in turn, somewhat inhibited the development of competitive microflora, but did not lead to its complete destruction. And the mycelium itself could not completely overcome it.

\section{Fermentation of used mushroom beds by em-products for compost}

During intensive cultivation of Pleurotus ostreatus different types of substrate are used: sunflower husk, corn stalks, and different types of straw. After receiving main products there is a problem in the disposal of the used mushroom beds. To date, there is no simple and at the same time cheap technology for waste disposal [12, p. 45]. Against the background of significant deterioration of agroecological indicators of soil and lack of ecologically balanced mechanisms of its replenishment with organic matter, which would be easily assimilated by soil biota, recuperation of used fungal beds with the help of EM-products and their conversion into highly nutritious organic fertilizer would solve a number of problems.

The scheme of the experiment on the recuperation of used mushroom beds consists of the following stages: 
1. Formation of drainage layer (branches, stalks of corn, etc.).

2. Formation of the first layer of used mushroom beds $(\mathrm{h}=300 \mathrm{~mm})$.

3. Treatment with the solution EM Bioactive or EM Compost with the concentration of $150 \mathrm{ml}$ per $1 \mathrm{~m} 3$ to intensify the processes of destruction of organic matter.

4. Formation of the filling layer $\mathrm{h}=50-150 \mathrm{~mm}$ (as a filler one can use sawdust, shavings, peat, soil, etc.).

5. Treatment with working solution EM Bioactive or EM Compost with the concentration of $150 \mathrm{ml}$ per $1 \mathrm{~m}^{3}$ to intensify the processes of destruction of organic matter.

6. Covering the compost mass with insulating layer (polyethylene film). The total height of the compost mass is $1.5-2 \mathrm{~m}$.

To obtain a highly nutritious organic fertilizer during the composting process, an important indicator is the ratio of carbon to nitrogen $(\mathrm{C}: \mathrm{N})$ in the compost mass. Depending on the nitrogen and carbon content, organic waste is divided into nitrogen-rich ("green") and carbon-rich ("brown") waste or materials. Used mushroom beds belong to the "brown" waste, and therefore in order to stimulate the effect of "self-heating" of the compost mass, we laid nitrogen-rich waste between the layers. For this purpose, we used cut grass, tops of vegetable plants etc. To obtain a ratio of C:N 25-30: 1 for 3 parts of used mushroom beds was added 1 part of plant impurities [13, p. 146].

In the process of maturation, the compost goes through four main stages: mesophilic (I), thermophilic (II), cooling (III), maturation (IV) (Figure 3.1).

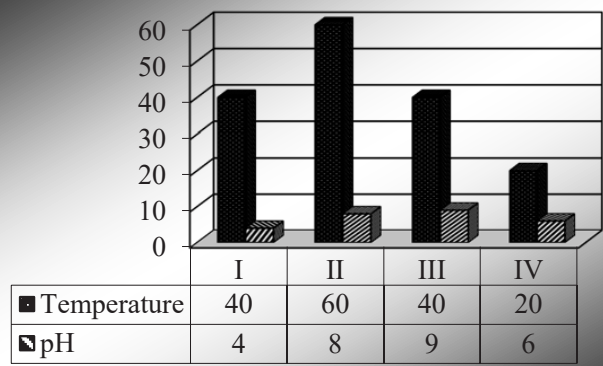

Figure 3.1. Main stages of composting 
At the first and second stages there is a self-heating due to chemical decomposition reactions at intensive activity of EM-bacteria and microorganisms. In the process of decomposition of easily decomposable substances, compost can heat up to the temperature of $65^{\circ} \mathrm{C}$. Under such temperature conditions, the vast majority of pathogens and weed seeds die, as evidenced by the change in $\mathrm{pH}$ of the compost mixture in the alkaline at the second and third stages. That is, there is a self-sterilization of the compost mass.

The third stage is the transformation of materials that are difficult to decompose into stable substances that form humus. The temperature begins to decrease; the compost becomes brown and gets the structure of the soil.

The fourth stage is the maturation of compost, which acquires a homogeneous structure and the smell of forest soil. There is a decrease in

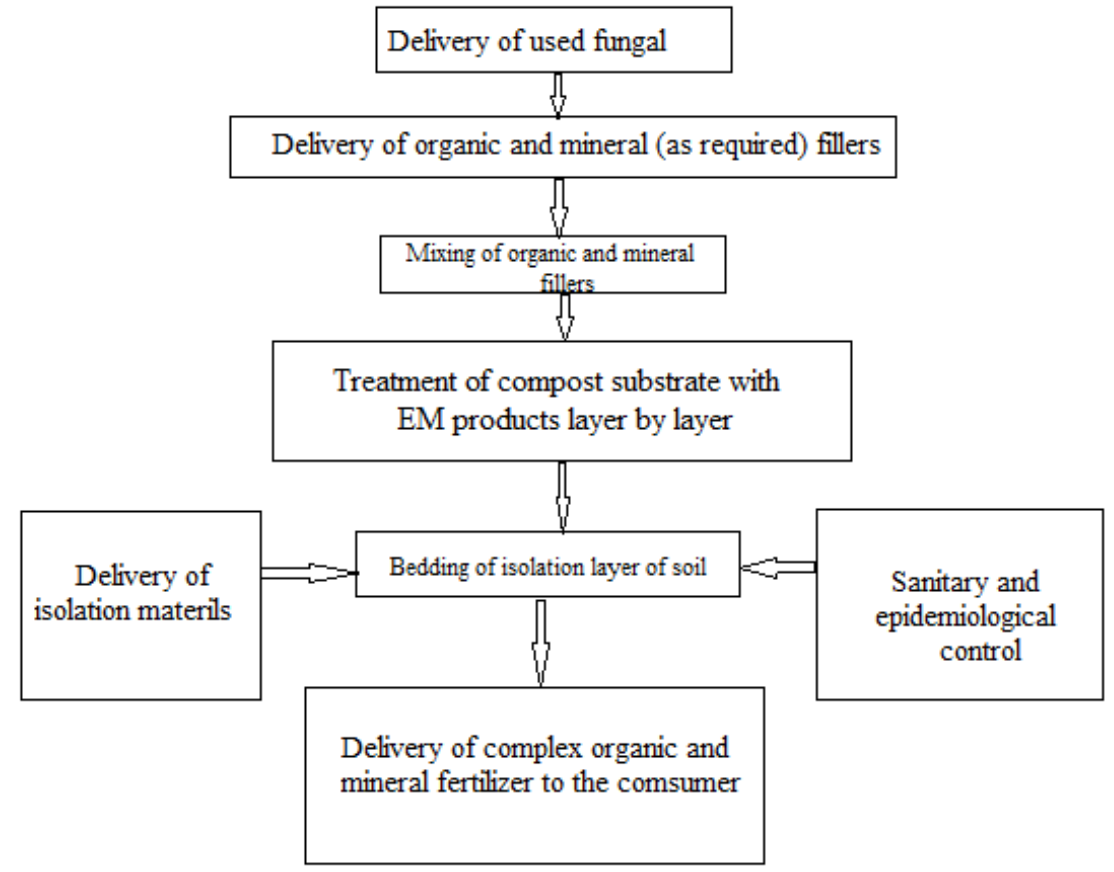

Figure 3.2. Technological scheme of utilization of used mushroom beds 
temperature and change in acidity (see Figure 3.1) The time required to convert waste into complete compost depends on many factors, such as temperature, humidity, raw materials for composting, composting method, use of additional means. However, to obtain hygienically safe compost, the composting process using EM-products takes 2-3 months.

Compost is considered ready when it does not distinguish the remnants of raw materials that are part of it, the mass becomes homogeneous, loose and dark, and weed seeds have lost the ability to germinate. The technological scheme of utilization of the used mushroom beds and getting highly nutritious organic fertilizer is presented in Figure 3.2.

\section{Formation of green mass of Alligator fennel under the influence of EM compost in the Northern Steppe of Ukraine}

EM compost was applied at $5 \mathrm{~kg} / \mathrm{m}^{2} ; 10 \mathrm{~kg} / \mathrm{m}^{2} ; 20 \mathrm{~kg} / \mathrm{m}^{2}$ for each land plot into the soil when sowing according to the scheme. Seeds were treated with EM Agro + EM $517 \mathrm{ml}+83 \mathrm{ml}$ of water for each plot. EM 5 is insect fungicide of biological origin. The scheme of the experiment is as follows:

1. Without fertilizer + planting width is $15 \mathrm{~cm}$

2. EM compost $5 \mathrm{~kg} / \mathrm{m}^{2}+$ planting width is $15 \mathrm{~cm}$

3. EM compost $10 \mathrm{~kg} / \mathrm{m}^{2}+$ planting width is $15 \mathrm{~cm}$

4. EM compost $20 \mathrm{~kg} / \mathrm{m}^{2}+$ planting width is $15 \mathrm{~cm}$

5. Without fertilizer + planting width is $30 \mathrm{~cm}$

6. EM compost $5 \mathrm{~kg} / \mathrm{m}^{2}+$ planting width is $30 \mathrm{~cm}$

7. EM compost $10 \mathrm{~kg} / \mathrm{m}^{2}+$ planting width is $30 \mathrm{~cm}$

8. EM compost $20 \mathrm{~kg} / \mathrm{m}^{2}+$ planting width is $30 \mathrm{~cm}$

The biological feature of Alligator fennel variety, like any other plant of the celery family [14, p. 98], is a long period of seed germination and uneven germination. This is due to the unstable soil temperature and moisture conditions that are characteristic of the spring period. Spring sowing was carried out at the soil temperature $+3 \ldots+5^{\circ} \mathrm{C}$.

Field germination of Alligator fennel seeds in the Northern Steppe zone in spring 2019 was $69-86 \%$, with planting width of $15 \mathrm{~cm}$ and $65-83 \%$ with the width of $30 \mathrm{~cm}$.

In the control, this figure was $55-56 \%$, respectively. Spring weather conditions were not conducive to friendly sprouts. April 2019 was relatively favorable for seed germination (Table 4.1). 
Table 4.1

Germination of fennel depending on technological methods, \%

\begin{tabular}{|c|c|c|c|c|c|}
\hline \multirow{2}{*}{$\begin{array}{c}\text { Sowing } \\
\text { time }\end{array}$} & \multirow{2}{*}{ Variant } & \multicolumn{4}{|c|}{ Planting width } \\
\cline { 3 - 6 } & & \multicolumn{2}{|c|}{$\mathbf{1 5} \mathbf{~ c m}$} & \multicolumn{2}{c|}{$\mathbf{3 0} \mathbf{~ c m}$} \\
\cline { 3 - 6 } & 1 & $55,6 \pm 5,1$ & $83,2 \pm 4,3$ & $56,1 \pm 3,8$ & $82,3 \pm 4,9$ \\
\hline \multirow{3}{*}{15.04} & 2 & $69,2 \pm 5,2$ & $85,0 \pm 5,5$ & $65,9 \pm 3,9$ & $85,5 \pm 5,3$ \\
\cline { 2 - 6 } & 3 & $75,4 \pm 4,8$ & $93,3 \pm 3,7$ & $74,5 \pm 4,8$ & $90,5 \pm 5,4$ \\
\cline { 2 - 6 } & 4 & $86,1 \pm 3,7$ & $95,2 \pm 4,1$ & $83,2 \pm 5,0$ & $94,3 \pm 5,0$ \\
\hline
\end{tabular}

These technological methods and doses of the product resulted in better survival of fennel plants, the number of which at the end of the growing season was $95.2 \%$.

The average data of phenological observations of spring crops on the growth and development of fennel plants showed that before the budding phase, the Alligator variety grows quite slowly (not more than $2-3 \mathrm{~cm}$ per decade). From budding to flowering, the growth rate increased threefold (almost $10 \mathrm{~cm}$ ) and the highest plant height (26.8) was observed at the doses of EM compost $20 \mathrm{~kg} / \mathrm{m}^{2}$ and narrow-row sowing method of $15 \mathrm{~cm}$ (Table 4.2).

Table 4.2

\section{Stages of fennel development in different phenological phases}

\begin{tabular}{|c|c|c|c|}
\hline \multirow{2}{*}{$\begin{array}{c}\text { Phenological } \\
\text { phase }\end{array}$} & \multirow{2}{*}{ Variant } & \multicolumn{2}{|c|}{ Plant height by planting width, cm } \\
\cline { 2 - 4 } & & $\mathbf{1 5} \mathbf{~ c m}$ & $\mathbf{3 0} \mathbf{~ c m}$ \\
\hline \multirow{4}{*}{ Sprouting } & 1 & $18,9 \pm 0,5$ & $14,2 \pm 0,3$ \\
\cline { 2 - 4 } & 2 & $19,0 \pm 0,5$ & $14,4 \pm 0,3$ \\
\cline { 2 - 4 } & 3 & $19,1 \pm 0,6$ & $15,0 \pm 0,5$ \\
\cline { 2 - 4 } & 4 & $19,6 \pm 0,7$ & $15,3 \pm 0,6$ \\
\hline \multirow{3}{*}{ Budding } & 1 & $20,3 \pm 1,0$ & $18,2 \pm 1,0$ \\
\cline { 2 - 4 } & 2 & $21,9 \pm 1,0$ & $19,4 \pm 1,1$ \\
\cline { 2 - 4 } & 3 & $22,3 \pm 1,0$ & $20,3 \pm 1,1$ \\
\hline \multirow{4}{*}{ Flowering } & 4 & $22,9 \pm 1,0$ & $20,6 \pm 1,1$ \\
\cline { 2 - 4 } & 1 & $25,6 \pm 1,1$ & $23,2 \pm 1,1$ \\
\cline { 2 - 4 } & 2 & $25,9 \pm 1,1$ & $23,4 \pm 1,1$ \\
\cline { 2 - 4 } & 3 & $26,0 \pm 1,2$ & $24,8 \pm 1,2$ \\
\hline
\end{tabular}


In the process of growth and development of fennel plants there was a tendency to increase the green mass of plants (stems, leaves, inflorescences). In the flowering phase, the leaf-stem mass was equal to 7.7-8.6 $\mathrm{g}$ of total plant weight, and in the seed formation phase it was 10.0-16.1 g (Table 4.3).

Table 4.3

\section{Dynamics of growth of main parts of aboveground mass of Alligator variety by variants}

\begin{tabular}{|c|c|c|c|c|c|c|}
\hline \multirow{3}{*}{ 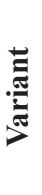 } & \multicolumn{3}{|c|}{ Narrow-row sowing method $(15 \mathrm{~cm})$} & \multicolumn{3}{|c|}{ Wide-row sowing method $(30 \mathrm{~cm})$} \\
\hline & \multicolumn{6}{|c|}{ Green mass of plants } \\
\hline & total & $\begin{array}{c}\text { Including } \\
\text { leaves and } \\
\text { stems }\end{array}$ & inflorescences & total & $\begin{array}{c}\text { Including } \\
\text { leaves and } \\
\text { stems } \\
\end{array}$ & inflorescences \\
\hline \multicolumn{7}{|c|}{ Flowering phase } \\
\hline 1 & $10,0 \pm 0,1$ & $8,5 \pm 0,1$ & $1,5 \pm 0,04$ & $8,7 \pm 0,2$ & $7,7 \pm 0,1$ & $1,0 \pm 0,02$ \\
\hline 2 & $10,0 \pm 0,1$ & $8,5 \pm 0,1$ & $1,5 \pm 0,04$ & $8,7 \pm 0,2$ & $7,7 \pm 0,1$ & $1,1 \pm 0,02$ \\
\hline 3 & $10,1 \pm 0,1$ & $8,6 \pm 0,1$ & $1,6 \pm 0,03$ & $8,9 \pm 0,2$ & $7,8 \pm 0,1$ & $1,1 \pm 0,02$ \\
\hline 4 & $10,2 \pm 0,1$ & $8,6 \pm 0,1$ & $1,6 \pm 0,02$ & $9,0 \pm 0,1$ & $7,8 \pm 0,1$ & $1,2 \pm 0,02$ \\
\hline \multicolumn{7}{|c|}{ Seed formation phase } \\
\hline 1 & $18,4 \pm 1,1$ & $15,0 \pm 0,4$ & $3,4 \pm 0,1$ & $12,1 \pm 0,2$ & $10,0 \pm 0,1$ & $2,1 \pm 0,02$ \\
\hline 2 & $18,7 \pm 1,1$ & $15,5 \pm 0,4$ & $3,4 \pm 0,1$ & $12,7 \pm 0,2$ & $10,5 \pm 0,1$ & $2,1 \pm 0,02$ \\
\hline 3 & $19,2 \pm 1,2$ & $15,8 \pm 0,3$ & $3,5 \pm 0,1$ & $13,0 \pm 0,2$ & $10,7 \pm 0,1$ & $2,4 \pm 0,02$ \\
\hline 4 & $19,5 \pm 1,2$ & $16,1 \pm 0,3$ & $3,6 \pm 0,1$ & $13,5 \pm 0,4$ & $11,0 \pm 0,1$ & $2,4 \pm 0,03$ \\
\hline
\end{tabular}

The use of microbial products in the experiment allows obtaining good indicators of individual productivity of Alligator fennel (Table 4.4).

Table 4.4

\section{Productivity of Alligator fennel by variants, $g$}

\begin{tabular}{|c|c|c|c|c|c|}
\hline \multirow{2}{*}{$\begin{array}{c}\text { Planting } \\
\text { width, } \\
\text { cm }\end{array}$} & \multirow{2}{*}{$\begin{array}{l}\text { Productivity } \\
\text { indicator }\end{array}$} & \multicolumn{4}{|c|}{ Variants } \\
\hline & & Control & $\begin{array}{c}\text { EM compost, } \\
5 \mathrm{~kg} / \mathrm{m}^{2}\end{array}$ & $\begin{array}{c}\text { EM compost, } \\
10 \mathrm{~kg} / \mathrm{m}^{2}\end{array}$ & $\begin{array}{c}\text { EM compost, } \\
20 \mathrm{~kg} / \mathrm{m}^{2}\end{array}$ \\
\hline \multirow{2}{*}{15} & Green mass & $715 \pm 22,1$ & $718 \pm 22,1$ & $725 \pm 22,1$ & $727 \pm 22,1$ \\
\hline & Seeds & $170 \pm 5,6$ & $171 \pm 5,6$ & $178 \pm 5,6$ & $180 \pm 5,6$ \\
\hline \multirow{2}{*}{30} & Green mass & $615 \pm 22,4$ & $620 \pm 22,4$ & $626 \pm 22,4$ & $628 \pm 22,4$ \\
\hline & Seeds & $145 \pm 3,9$ & $148 \pm 3,9$ & $150 \pm 3,9$ & $152 \pm 3,9$ \\
\hline
\end{tabular}


The productivity of fennel using EM compost differed from the individual productivity of plants in the control areas. With the narrow-row method of sowing the largest amount of green mass from the area was $727 \mathrm{~g}$ and seed yield equaled $180 \mathrm{~g}$ in the fourth variant, compared with the wide-row method of sowing, respectively, $628 \mathrm{~g}$ and $152 \mathrm{~g}$. This difference is quite natural, because pcs $/ \mathrm{m} 2$ against 25 with $30 \mathrm{~cm}$ of planting width [15, p. 60].

It is important to note that the yield of green mass and seeds in 3 and 4 variants differ within small limits for both methods of sowing. Therefore, the use of EM compost in doses greater than $20 \mathrm{~kg} / \mathrm{m} 2$ is impractical and economically unprofitable.

\section{Conclusions}

Taking in consideration current state of agricultural land in Ukraine, there is an urgent need to develop alternative management systems based on organic systems.

The proposed technological methods of the organization of agroeco complex will ensure ecological safety of agricultural products, creating closed cycles of production, resource conservation, monitoring of all stages of production and product control, energy independence of the agrocomplex at all stages of agricultural production.

Thus, considering the afore-mentioned we can draw the following conclusions:

1) Treatment of straw substrate with EM products and layer-by-layer inoculation helps to reduce the time of fouling in the intensive biotechnology for growing Oyster mushroom;

2) Increase of biological productivity of Oyster mushroom introducing the technology of treatment of substrate offered by us promotes fast fouling of the bed by hyphae of a mycelium, due to destruction of hemicellulose and lignin, and also suppression of competitive microflora;

3) EM compost is environmentally friendly and balanced organomineral fertilizer;

4) The use of EM technologies allows controlling the composition of species of micro flora and micro fauna at all stages of composting;

5) Application of EM technologies provides unlimited range for the recuperation of any organic waste (various types of manure and organic industrial waste); 
6) Biometric indicators of Alligator fennel, data on the yield of green mass and seeds clearly indicate that the use of EM compost of $20 \mathrm{~kg} / \mathrm{m} 2 \mathrm{has}$ most positive effect on the formation of marketable qualities of fennel plants;

7) The average data from the experimental plots clearly indicate that the use of narrow-row sowing method $(15 \mathrm{~cm})$ increases green mass, compared with wide-row sowing method, as it increases crop density. At the same time, wide-row method of sowing provides better quality seeds [16, p. 92].

\section{References:}

1. Huz' M.M., \& Sobchenko T.S. (2018). Orhanichne zemlerobstvo: problemy ta oriyentyry rozvytku v Ukrayini [Organic farming: problems and guidelines for development in Ukraine]. Molodyi vchenyi - Young scientist, 6(58), 196-199. (in Ukrainian)

2. Rohalska I.O. (Eds.) (2015). Systemy suchasnykh intensyvnykh tekhnolohiy $\mathrm{u}$ roslynnytstvi [Systems of modern intensive technologies in crop production]. Vinnytsia. (in Ukrainian)

3. Ivanov A.I. (1989). Metodyka otsenky urozhaynosty novykh shtammov veshenky [Methods for assessing productivity of new strains of oyster mushrooms]. Mykolohyia y fytopatolohyia - Mycology and phytopathology, 23, 485-487. (in Russian)

4. Kholodnyy sposib pidhotovky solom'yanykh substrativ za dopomohoyu EM-preparativ [Cold method of preparation of straw substrates using EM-products]. (2020). Patent 142316 Ukrainy - Patent 142316 Ukraine: International Patent Classification A01B 79/00 (2006.01) from 5d May 2020. Kyiv: Ukrpatent. (in Ukrainian)

5. Vdovenko S.V. (2011). Vyroshchuvannia yistivnykh hrybiv [Cultivation of edible mushrooms]. Vinnytsia: Navch. posibn. (in Ukrainian)

6. Ovcharuk V.I. (2013). Ekolohichna osoblyvist hlyvy zvychainoi za ekstensyvnoho sposobu vyroshchuvannia [Ecological peculiarity of oyster mushrooms for extensive cultivation method]. Naukovyi visnyk NLTU Ukrainy - Scientific Bulletin of the National Forestry University of Ukraine, 23.18, 48-52. (in Ukrainian)

7. Mironycheva E., \& Kyurcheva L. (2010). Kachestvennye kharakterystyky tovarnykh hrybov [Qualitative characteristics of marketable mushrooms]. Ovoshchevodstvo: zhurnal dlya dachnikov i sadovodov - Vegetable growing: magazine for summer residents and gardeners, 2, 79-80. (in Russian)

8. Dospekhov B.A. (1985). Metodyka polevoho opyta (s osnovamy statisticheskoi obrabotki rezul'tatov yssledovaniy) [Methods of field experience (with the basics of statistical processing of research results)]. 5th edition (revised). Moscow: AGROPromizdat. (in Russian)

9. Kovalov M.M., \& Reznichenko V.P. (2019). Rozroblennia enerhozaoshchadzhuiuchoi tekhnolohii vyroshchuvannia hlyvy zvychainoi za rakhunok vyko- 
rystannia EM-preparativ [Development of energy-saving technology for cultivation of oyster mushrooms due to application of EM solutions]. Tavriiskyi naukovyi visnyk: Naukovyi zhurnal. Silskohospodarski nauky - Tavriyskyi Scientific Bulletin: Scientific Journal. Agricultural Sciences, 108, 34-38. (in Ukrainian)

10.Kovalov M.M., \& Mostipan M.I., \& Mashchenko Y.V. (2020). Vplyv EM preparativ na formuvannya vrozhayu riznykh shtamiv hlyvy zvychaynoyi [Influence of EM products on the formation of productivity of different strains of oyster mushroom]. Tavriiskyi naukovyi visnyk: Naukovyi zhurnal. Silskohospodarski naukyTavriyskyi Scientific Bulletin: Scientific Journal. Agricultural Sciences, 111, 83-87. (in Ukrainian)

11. Gaisler L.I. (1989). Vyrashchyvanye hrybov shampyn'onov $i$ veshenky obyknovennoi [Growing champignons and oyster mushrooms]. Chisinau. (in Russian)

12. Bogdanovskaya Zh.N. (1986). Mikrobiologicheskaya transformatsia tselyulozo-soderzhashchikh materialov [Microbiological transformation of cellulose-containing materials]. Nauka i tekhnika - Science and technology, 13-47. (in Ukrainian)

13. Kovalov M.M. (2019). Otrymannya netradytsiynykh orhanichnykh dobryv za dopomohoyu EM preparativ [Obtaining non-traditional organic fertilizers using EM products]. Proceedings from 12: Materialy XII Mizhnarodnoi naukovo-praktychnoi konferentsii «Problemy konstruiuvannia, vyrobnytstva ta ekspluatatsii silskohospodarskoi tekhniky» - The Twelfth International Scientific and Practical Conference «Problems of Design Production and Operation of Agricultural Machinery», (pp.146-148). Kropyvnytskyi: CUNTU. (in Ukrainian)

14.Knyazyuk O.V., \& Kozak V.V. (2017). Vplyv strokiv sivby ta shyryny mizhryad' na formuvannya produktyvnosti kropu zapashnoho (Anethum graveolens L.) [Influence of sowing dates and row spacing on the formation of productivity of fennel (Anethum graveolens L.)]. Ahrobiolohiia: zbirnyk naukovykh prats Bilotserkivskoho natsionalnoho ahrarnoho universytetu - Agrobiology: Collection of Scientific Works. Bila Tserkva National Agrarian university, 2, 98-101. (in Ukrainian)

15.Uniyaka T.L. (2005). Vrozhaynist' nasinnya kropu zapashnoho (Anethum graveoles L.) za riznykh strokiv sivby v Lisostepu Ukrayiny [Productivity of fennel seeds (Anethum graveoles L.) at different sowing dates in the Forest-Steppe of Ukraine]. Sortovyvchennya ta okhorona prav na sorty roslyn - Variety research and protection of plant variety rights, 2, 55-63. (in Ukrainian)

16. Kovalov M.M., \& Topolnyi F.P. (2020). Formuvannya zelenoyi masy kropu sortu Alihator pid vplyvom EM preparativ v umovakh Pivnichnoho Stepu Ukrayiny. [Formation of green mass of fennel variety Alligator under the influence of EM products in the Northern Steppe of Ukraine]. Tavriiskyi naukovyi visnyk: Naukovyi zhurnal. Silskohospodarski nauky - Tavriyskyi Scientific Bulletin: Scientific Journal. Agricultural Sciences, 112, 88-92. (in Ukrainian) 